\title{
Antifungal Activity of Pseudomonas fluorescens Metabolites against some Phytopathogenic Fungi
}

\author{
Omnia M. Mohamed ${ }^{1}$, Rania A. A. Hussein ${ }^{1}$, Mona H. Badawi ${ }^{2}$ and Hussien E. Makboul ${ }^{2}$ \\ ${ }^{1}$ Central Agricultural Pesticide Laboratory, Agriculture Research Center, Giza, Egypt. \\ ${ }^{2}$ Department of Agricultural Microbiology, Faculty of Agriculture, Cairo University, Egypt.
}

Received: 20 Jan 2020 / Accepted 30 Mar. 2020 / Publication date: 10 April. 2020

\begin{abstract}
The effects of Pseudomonas fluorescens culture, culture filtrate and the crude antibiotics extracted from culture filtrate were in vitro studied against six plant pathogenic fungi (Fusarium oxysporium, Fusarium solani, Fusarium semitectium, Rhizoctonia solani, Sclerotium rolfsii and Botrytis cinerea). P. fluorescens effectively inhibited the mycelial growth of all fungi in dual culture tests. Also, the culture filtrate at different concentrations reduced the mycelial growth except $S$. rolfsii. The culture filtrate at the $\mathrm{EC}_{50}$ concentration was effective in reducing the total contents of soluble sugars, free amino acids, total proteins and enzyme activities produced by the phytopathogenic fungi. The antifungal compounds were extracted with equal volume of ethyl acetate. The antifungal compounds from $P$. fluorescens at $100 \mathrm{mg} \mathrm{ml}^{-1}$ completely inhibited $F$. oxysporium and $S$. rolfsii and purified by column puriflash and re-tested for antifungal activity. The major compound in the crude antibiotics was characterized by TLC, mass spectrometry and FTIR. The molecular weight of this compound was $255.4 \mathrm{~m} / \mathrm{z}$. In FTIR analysis, antifungal compound extracted from $P$. fluorescens revealed absorption at 3318.13 per $\mathrm{cm}$ pyrrole ring and $\mathrm{CH} 3$ (stretch) (1450.2) and $\mathrm{C}=\mathrm{C}$ aromatic weak intensity (1662.44), $\mathrm{C}^{-\mathrm{Cl}_{2}}$ (624.81). This confirms that the antifungal compound in crude extract is pyrrolnitrin.
\end{abstract}

Keywords: P. fluorescens, pyrrolnitrin, phytopathogenic fungi, secondary metabolites

\section{Introduction}

It is well known that fungal diseases are among the main constrains affecting production of crops both in terms of quality and quantity all over the world. Although chemical control usually achieves considerable results, thought it causes many problems to the environment and human health. Biological control is promising and safe in this respect. P. fluorescens encompasses a group of common, nonpathogenic saprophytes that colonize soil, water and plant surface environments. It secretes a soluble greenish fluorescent pigment called fluorescein, particularly under conditions of low iron availability. Secondary metabolites are small heterogenous organic molecules, that display prominent ecological benefits to the host organisms in providing defense against predators, parasites, diseases, interspecies nutritional competence, and competitive edge over interaction with the environment (Dixon, 2001). P. fluorescens isolates possess a variety of promising properties of antifungal activity due to its secondary metabolites which make it as a biocontrol agent (Kliebenstein, 2004).

The ability of $P$. fluorescens to suppress phytopathogenic fungi depends on its ability to produce some antibiotic metabolites such as pyoluteorin, pyrrolnitrin, phenazine 1- carboxylic acid, 2, 4 diacetylphloroglucinol, hydrogen cyanide, kanosamine, pyocyanin and viscosinamide (Prabhukarthikeyan and Raguchander, 2016). In this investigation, attempts were made to study the activity of $P$. fluorescens against some phytopathogenic fungi and identify some of its antifungal compounds and testing their antifungal activities.

\section{Materials and Methods}

\section{Bacterial strain}

The bacterial strain P. fluorescens used in the present study was obtained from Soils, Water and Environment Research Institute, Agricultural Research Center (ARC), Giza, Egypt.

Corresponding Author: Omnia M. Mohamed, Central Agricultural Pesticide Laboratory, Agriculture Research Center, Giza, Egypt. E-mail: Omniamostafa645@gmail.com 


\section{Fungal pathogens}

Naturally-diseased tomato plants showing root rot and wilt symptoms were collected from private fields from Benisewif and Quliubia governorates. Plant root and stem samples were washed carefully with tap water to remove the adhering soil particles, cutted into small pieces $(1 \mathrm{x} 1 \mathrm{~cm})$ and surface-sterilized by immersion in $5 \%$ sodium hypochlorite for $5 \mathrm{~min}$ according to the method of Burr et al. (1978). The segments were rinsed three times in sterilized distilled water, dried between two sterilized filter papers and transferred under aseptic conditions to sterilized Petri dishes containing potato dextrose agar medium (PDA). Plates were incubated at $27{ }^{\circ} \mathrm{C}$ and developed colonies were picked after 5 days, isolated on PDA plates and purified using the single spore and hyphal tip techniques (Dhingra and Sinclair, 1984). The isolated fungi were identified microscopically to species level according to Nelson et al. (1983) and Barnett and Hunter (1987). Stock cultures were maintained on PDA slants and kept at $10{ }^{\circ} \mathrm{C}$ in refrigerator for further experiments. The identification was verified in Plant Pathology Department, Faculty of Agriculture, Cairo University.

\section{Antibiosis of the bacterial strain towards pathogenic fungi}

For the tested bacterial strain, mother culture or its filtrate was used to test the antagonistic effects against the pathogenic fungi.

\section{Mother cultures}

Petri dishes ( $9 \mathrm{~cm}$ in diameter), each containing $20 \mathrm{ml}$ PDA medium were surfacely seeded with discs ( $5 \mathrm{~mm}$ in diameter) of each tested pathogen, taken from 5 day-old cultures. Discs were placed near the edge of each Petri dish and on the other side at the same time, plates were streaked with the bacterial strain. Plates inoculated only with the pathogens were used as control. Three replicates were prepared for each treatment. Plates were incubated at $27-28{ }^{\circ} \mathrm{C}$ for $5-7$ days and zones of inhibition were recorded when the mycelium mats of pathogens cover the medium surface of the control plates (Siddiqui, 2001).

\section{Culture filtrate}

The bacterial strain was inoculated in Kings B broth medium and incubated at $28{ }^{\circ} \mathrm{C}$ on a shaker for $96 \mathrm{hrs}$. The liquid culture was centrifuged at $10000 \mathrm{rpm}$ for $30 \mathrm{~min}$ and the supernatant was passed through a $0.045 \mu \mathrm{m}$ millipore filter. The culture filtrate was kept at $4{ }^{\circ} \mathrm{C}$ for further use.

Cell-free bacterial culture was added to PDA to obtain 5, 10, 15 and $20 \%$ concentrations of the filtrate. Thereafter, media were poured in sterile Petri dishes and allowed to solidify, PDA without culture filtrate was used as control. Media were then surfacely seeded with $5 \mathrm{~mm}$ discs of 5-7-day old pathogenic fungal cultures. Petri dishes were incubated for $5-7$ days at $25 \pm 2{ }^{\circ} \mathrm{C}$, inhibition zone diameters were measured. Percentages of growth inhibition were calculated using the following formula:

$$
\text { Growth inhibition \% = R1-R2/ R1 X } 100
$$

where: $\mathrm{R}_{1}$, the radius of normal growth in control; $\mathrm{R}_{2}$, the radius of the inhibited growth in the treatment (Abd El-Ghany, 2001).

\section{Effect of culture filtrates of Pseudomonas flurocences at $\mathrm{EC}_{50}$ on chemical components and enzymes produced by pathogenic fungi}

The $\mathrm{EC}_{50}$ concentration of bacterial culture filtrate was added to $100 \mathrm{ml}$ of sterilized PD medium inoculated with 4 discs $(5 \mathrm{~mm})$ of either tested fungi and incubated at $\left(25 \pm 2{ }^{\circ} \mathrm{C}\right)$. Four flasks were used for each treatment. When the mycelium growth covered the surface of media in untreated flask (control), the mycelium matrix was excluded by filtration and dried at ambient temperature overnight. The dry mycelia mates were homogenated and determined for chemical constituents.

\section{Chemical determinations of fungi}

\section{Total soluble sugars} 1995).

Total soluble sugars were determined according to Shaffer-Somogi micro method (AOAC, 


\section{Free amino acids as lysine}

Samples were prepared by extracting $0.5 \mathrm{~g}$ of each fungal culture by $25 \mathrm{ml}$ methanol $80 \%$ (Jayaraman, 1985). A standered solution of lysine was prepared by dissolving $0.02 \mathrm{~g}$ lysine in $100 \mathrm{ml}$ of $80 \%$ ethanol. The color developed was measured using a spectrophotometer at wave length $570 \mathrm{~nm}$.

\section{Total protein}

A ratio of 1:2.5 (w/v) of each fungus to extraction buffer (0.125M Tris-borate, $\mathrm{pH} 8.9)$ was used. The soluble protein concentrations were spectroscopically determined by referring to a calibration curve relating to the concentration of authentically albumin bovine at $546 \mathrm{~nm}$ according to Lowery et al. (1951).

\section{Enzymatic activity measurements \\ Total amylase activity}

One gram of each fungus was homogenized in a mortar with $4 \mathrm{ml}$ of $0.01 \mathrm{M}$ Tris- $\mathrm{HCl}$ buffer $\mathrm{pH}$ 8.0 containing $0.02 \mathrm{M} \mathrm{NaCl}$ and $\mathrm{CaCl}_{2}$. The supernatant was used for total amylase activity according to the method described by Dewez et al. (2005). The total amylase activity is expressed as mg starch consumed $/ 15 \mathrm{~min} / \mathrm{g}$ fungus.

\section{Peroxidase activity}

One gram of each fungus was extracted two times with $0.1 \mathrm{M}$ potassium phosphate buffer $\mathrm{pH}$ 4.7 containing $0.25 \mathrm{M}$ sucrose. The colorimetric assay of total peroxidase activity was measured as recommended by Sreenivasulu et al. (1999). The peroxidase activity was expressed in a unit of the increase of absorption at $470 \mathrm{~nm}$ for 5 min per g fungus, designated as OD $470 \mathrm{~nm} / 5 \mathrm{~min} / \mathrm{g}$ fungus.

\section{Protease activity}

Protease activity was determined by the method described by Dewez et al. (2005). The blue color developed was determined after 5 min at $625 \mathrm{~nm}$.

\section{Effects of Pseudomonas flurocesnces metabolites}

\section{Extraction of antifungal compounds}

The bacterial strain was allowed to grow in $200 \mathrm{ml}$ of pigment production broth medium (peptone, $20 \mathrm{~g}$; glycerol, $20 \mathrm{ml} ; \mathrm{NaCl}, 5 \mathrm{~g} ; \mathrm{KNO}_{3}, 1 \mathrm{~g}$; distilled water 1 1; $\mathrm{pH} 7.2$ ) for 4 days on rotary shaker at $30{ }^{\circ} \mathrm{C}$. The fermentation broth was centrifuged at $3500 \mathrm{rpm}$ for five minutes and the supernatant was collected. It was acidified to $\mathrm{pH} 2.0$ with $1 \mathrm{~N} \mathrm{HCl}$ then extracted with an equal volume of ethyl acetate. The ethyl acetate extract was reduced to dryness in vacuo. The residues were dissolved in methanol and kept at $4{ }^{\circ} \mathrm{C}$ until use for TLC (Mallaiah et al., 2017).

\section{Antifungal activity of ethyl acetate crude extract}

The residues of ethyl acetate extract was dissolved in DEMSO to determine the antagonistic activity of crude extract at the concentrations $25,50,75$ and $100 \mathrm{mg} \mathrm{ml}^{-1}$, added to PDA media, poured in sterile Petri dishes and allowed to solidify, PDA without crude extract was used as control. Media were then surfacely seeded with $5 \mathrm{~mm}$ discs of 5-7-day old pathogenic fungal cultures. Petri dishes were incubated for 5-7 days at $25 \pm 2{ }^{\circ} \mathrm{C}$, inhibition zone diameters were measured. Percentages of growth inhibition were calculated using the following formula:

Growth inhibition $\%=\mathrm{R}_{1}-\mathrm{R}_{2} / \mathrm{R}_{1}$ X 100

where : $R_{1}$, the radius of normal growth in control; $R_{2}$, the radius of the inhibited growth in the treatment (Abd El-Ghany, 2001).

\section{Scanning electron microscopy of the hyphal morphology}

The protocols described by Trolezi et al. (2017) was followed for SEM analysis. Hyphal fragments were collected and washed three times in $0.1 \mathrm{M}$ phosphate buffer solution (PBS), then, fixed in $2.5 \%$ glutaraldehyde (Merck) in $0.1 \mathrm{M} \mathrm{PBS}$ at $4{ }^{\circ} \mathrm{C}$ for $1 \mathrm{~h}$ and washed in the same buffer. Samples were dehydrated with a graded ethanol series. The Emitech K500X sputter coater (Quorum 
Technologies) was used for gold sputtering of SEM samples. The hyphal morphology was evaluated by the S-3000N scanning electron microscope (Hitachi).

\section{Purification of the ethyl acetate crude extract}

The crude extract was applied to thin layer chromatography (TLC) plate for further purification using the mixture of acetonitrile / methanol /water (1:1:1) as a solvent system. Crude extract was separated by puriflash column 30 silica HP $-25.0 \mathrm{~g}$ (22 bar). The dried concentrated sample was dissolved in $5 \mathrm{ml}$ of hexane and loaded onto the silica gel column and solvent system comprising hexane and ethyl acetate at a flow rate of $15 \mathrm{ml} \mathrm{min}$. The eluted fractions were collected. The fractions were pooled and concentrated by evaporation at $40^{\circ} \mathrm{C}$ using rotary evaporator.

\section{Thin-layer chromatography (TLC)}

Thin layer chromatography (TLC) was performed on silica gel TLC- cards G25-UV 254 plates for purification using a mixture of acetonitrile/methanol/water (1:1:1) as a solvent system (Rosales et al.,1995). TLC of the prepared crude extract was performed with precoated silica and was observed under UV light (254 nm).

\section{Mass spectroscopy}

The molecular weight of the fraction 1 was determined using Quick mass determination (Probe / TLC-MS) at Nawah Scientific Research, Cairo, Egypt.

\section{Fourier-Transform Infrared Spectroscopy (FTIR Spectroscopy)}

The purified fraction 1 was subjected to FTIR spectroscopic analysis. FTIR was carried out by mixing the sample with finely grounded $\mathrm{KBr}$. The parameters used in FTIR analysis were spectral range between 4000 and $400 \mathrm{~cm}^{-1}$. Upon pressing under $2000 \mathrm{kPa}$, pellet disc obtained was analyzed using JASCO FTIR -3600 infrared spectrometer by employing $\mathrm{KBr}$ pellet technique, equipped with $\mathrm{KBr}$ beam splitter with DTCS (Deuterated triglycine sulfate detector $\left(7800-350 \mathrm{~cm}^{-1}\right)$ at the National Center for Radiation Research and Technology (NCRRT), Atomic Energy Authority, Egypt.

\section{Statistical analysis}

Data were subjected to analysis of variance (ANOVA) (Gomez and Gomez, 1984), followed by Duncan's multiple range tests to compare means (Duncan, 1955).

\section{Results and Discussion}

\section{Isolation, purification and identification of fungi}

The isolated fungi were identified as Fusarium solani, Fusarium oxysporium, Fusarium semitectium, Rhizoctonia solani and Sclerotium rolfsii. All fungi were isolated from root, stem and rhizosphere of tomato seedlings, while Botrytis cinerea was isolated from the fruit of tomato plant.

\section{Antagonistic effect of $\boldsymbol{P}$. fluorescens against fungal pathogens}

Fusarium solani, Rhizoctonia solani and Fusarium semitectium were the main fungi causing root rot disease in several plants (Karima et al., 2012). While Botrytis cinerea, the agent of gray mold, is a facultative phytopathogenic fungus that attacks flowers, fruits, leaves and stem of more than 200 plant species (Li Hue et al., 2018). Disease caused by this fungus produces considerable losses to crops in the field and during storage. Sclerotium rolfsii, is a destructive stem and crown rot of tomato. White mycelium spread over stems of infected plants and formed sclerotia on the old lesions nearby soil surface. Fusarium oxysporium f. sp lycoperisici causes soil borne vascular wilt disease in the tomato plant (Van der Does et al., 2018).

The previous fungi traditionally controlled by commercial fungicides has caused serious problem, such as the appearance of highly resistant strains and the contamination of soil and water, while the bacterial bioagents are an alternative to chemical fungicides. For this reasons, this study investigats the effects of the bacterial bioagent Pseudomonas flurocences, against the phytopathogenic fungi. P. fluorescens significally inhibited the mycelium growth of all tested fungi. The highest 
inhibition zone was recorded against Botrytis cinerea $(23 \mathrm{~mm})$ followed by Fusarium oxysporium (21 $\mathrm{mm})$. On the other hand, Pseudomonas flurocences showed the lowest inhibition zone with R. solani (9 $\mathrm{mm}$ ). Fluorescent pseudomonads have an antagonistic effect that is not necessarily associated with the antibiotics that were searched for here. Several reports on plant-associated pseudomonads indicated also a role of siderophores, lytic enzymes, hydrogen cyanide and ammonia as well as organic volatiles in the inhibition of fungal phytopathogens (Alimi et al., 2012; Loper et al., 2012; Zhang et al., 2014; De Vrieze et al., 2015; Yasmin et al., 2016; Wagner et al., 2018).

Effect of Pseudomonas fluorescens culture filtrate on the linear growth of phytopathogenic fungi

Data presented in Table (1) show the effect of Pseudomonas fluorescens culture filtrate on the tested phytopathogenic fungi. The culture filtrate had inhibitory effects on the pathogenic fungi except the fungus Sclerotium rolfsii. The highest percentage of reduction in mycelial growth (72) was obtained at $20 \%$ concentration on $F$. semitectium, followed by $F$. solani and F.oxysporium $(70.4$ and $70 \%$ respectively) at the same concentration, whereas the lowest effect was recorded on $R$. solani (19.4\%).

The lowest $\mathrm{EC}_{50}$ (4.53) was recorded with $F$. oxysporium followed by $F$. solani and $F$. semitectium (7.052 and 8.79 respectively) whereas the highest $\mathrm{EC}_{50}$ was recorded with $B$. cinerea (10.67). Data proved that $S$. rolfsii and $R$. solani seem to be resistant or tolerant to $P$. fluorescens culture filtrate than B. cinerea and Fusarim species. Rohit et al. (2011) proposed that application of culture filtrate of plant growth promoting rhizobacteria (PGPRs) i.e. Bacillus subtilis MA-2 and Pseudomonas fluorescens MA-4 inhibited the growth of phtytopathogens infecting selected medicinal and aromatic plants, indicating that suppression was due to antifungal compounds in the filtrate.

Table 1: Inhibitory effects (\%) of Pseudomonas fluorescens culture filtrate at different concentrations against pathogenic fungi

\begin{tabular}{lccccc}
\hline Phytopathogenic fungi & $\mathbf{2 0}$ & $\mathbf{1 5}$ & $\mathbf{1 0}$ & $\mathbf{5}$ & $\mathbf{E C}_{\mathbf{5 0}}$ \\
\hline $\boldsymbol{F}$. solani & $70.4^{\mathrm{ab}}$ & $62^{\mathrm{b}}$ & $57.4^{\mathrm{b}}$ & $43.5^{\mathrm{b}}$ & 7.052 \\
$\boldsymbol{F}$. oxysporium & $70^{\mathrm{ab}}$ & $65.7^{\mathrm{a}}$ & $60^{\mathrm{a}}$ & $51.8^{\mathrm{a}}$ & 4.53 \\
$\boldsymbol{F}$. semitecctium & $72^{\mathrm{a}}$ & $64.4^{\mathrm{a}}$ & $55.5^{\mathrm{b}}$ & $33^{\mathrm{c}}$ & 8.79 \\
$\boldsymbol{R}$. solani & $19.4^{\mathrm{c}}$ & $0^{\mathrm{d}}$ & $0^{\mathrm{d}}$ & $0^{\mathrm{d}}$ & - \\
$\boldsymbol{S}$. rolfisii & $0^{\mathrm{d}}$ & $0^{\mathrm{d}}$ & $0^{\mathrm{d}}$ & $0^{\mathrm{d}}$ & - \\
B. cinerea & $66.6^{\mathrm{b}}$ & $50^{\mathrm{c}}$ & $43^{\mathrm{c}}$ & $42.6^{\mathrm{b}}$ & 10.67 \\
Control & $0^{\mathrm{d}}$ & $0^{\mathrm{d}}$ & $0^{\mathrm{d}}$ & $0^{\mathrm{d}}$ & - \\
\hline
\end{tabular}

Means follow by the same letters are statistically insignificant.

Effect of culture filtrate of Pseudomonas fluorescens on the biochemical components produced by phytopathogenic fungi

Results in Table (2) proved that, the PD liquid medium treated with $P$. fluorescens culture filtrate induced significant decreases in total soluble sugars for four tested fungi comparing with untreated one. Such effects were highly pronounced in case of treated $F$. oxysporium and $F$. semitectium with culture filtrate which reached 46.6 and $41.7 \%$ respectively of that recorded in untreated one. Moderate decreases in total soluble sugars for $F$. solani and B. cinerea reached 26.8 and $24.28 \%$ respectively.

The reduction of free amino acids for phytopathogenic fungi was observed due to treatment with the culture filtrate. Such effect was highly significant in case of $F$. oxysporium and $F$. semitectium. The reduction percentages of free amino acids for $F$. semitectium, $F$. oxysporium, $F$. solani and $B$. cinerea were $36.35,35.3,16.56$ and 18.2 respectively. The same trend was found with the reduction in total protein for the four tested fungi. The reduction of total protein was highly significant in case of $F$. oxysporium which reached $44.64 \%$ of that recorded in untreated.

Amylase activity in $F$. oxysporium and $F$. solani sharply reduced due to treatment with the culture filtrate comparing with untreated which reached 48 and $40 \%$ respectively. The lowest effect was observed in case of $B$. cinerea which recorded $16 \%$ reduction in amylase activity of that obtained in untreated corresponding. Both protease and peroxidase activities for all tested fungi showed moderate reductions compared with controls fungi. 
Table 2: Effects of Ps. fluorescens culture filtrate on total soluble sugars, free amino acids, total protiens and enzymes activities produced by phytopathogenic fungi

\begin{tabular}{|c|c|c|c|c|c|c|}
\hline \multirow[b]{2}{*}{$\begin{array}{l}\text { Phytopathogenic } \\
\text { fungi }\end{array}$} & \multicolumn{6}{|c|}{ Biochemical component } \\
\hline & $\begin{array}{l}\text { Total } \\
\text { soluble } \\
\text { sugars } \\
\text { (g/1g fungus) }\end{array}$ & $\begin{array}{l}\text { Free amino } \\
\text { acids } \\
\text { (mg/1g } \\
\text { Fungus) }\end{array}$ & $\begin{array}{l}\text { Total } \\
\text { protein } \\
\text { (mg/1g } \\
\text { Fungus) }\end{array}$ & $\begin{array}{l}\text { Amylase } \\
\text { activity } \\
\text { (mg } \\
\text { starch/1g } \\
\text { Fungus) } \\
\end{array}$ & $\begin{array}{l}\text { Protease } \\
(\text { O.D/ 5min) }\end{array}$ & $\begin{array}{l}\text { Peroxidase } \\
\text { activity } \\
(\mathbf{O} . \mathrm{D} / \\
5 \mathrm{~min})\end{array}$ \\
\hline F. solani & $0.030^{b}$ & $40.7^{b}$ & $2.967^{b}$ & $1.2^{\mathrm{b}}$ & $0.40^{b}$ & $0.2467^{b}$ \\
\hline Control & $0.041^{\mathrm{a}}$ & $50.6^{\mathrm{a}}$ & $4.5^{\mathrm{a}}$ & $2.5^{\mathrm{a}}$ & $0.53^{\mathrm{a}}$ & $0.3367^{\mathrm{a}}$ \\
\hline$\%$ Reduction & 26.8 & 19.56 & 33.3 & 40 & 23.07 & 26.73 \\
\hline F. oxysporium & $0.016^{\mathrm{b}}$ & $33.1^{\mathrm{b}}$ & $3.1^{\mathrm{b}}$ & $1.3^{b}$ & $0.30^{b}$ & $0.40^{\mathrm{b}}$ \\
\hline Control & $0.030^{\mathrm{a}}$ & $51.2^{\mathrm{a}}$ & $5.6^{\mathrm{a}}$ & $2.5^{\mathrm{a}}$ & $0.41^{\mathrm{a}}$ & $0.506^{\mathrm{a}}$ \\
\hline$\%$ Reduction & 46.6 & 35.3 & 44.64 & 48 & 21.95 & 20.9 \\
\hline F. semitecctium & $0.1166^{b}$ & $25.67^{b}$ & $5.6 \mathrm{~b}$ & $3.2^{b}$ & $0.30^{b}$ & $0.4500^{b}$ \\
\hline Control & $0.20^{\mathrm{a}}$ & $40.33^{\mathrm{a}}$ & $7.16^{\mathrm{a}}$ & $4.30^{\mathrm{a}}$ & $0.4^{\mathrm{a}}$ & $0.550^{\mathrm{a}}$ \\
\hline$\%$ Reduction & 41.7 & 36.35 & 22.2 & 25.58 & 25 & 18.2 \\
\hline B. cinerea & $0.053^{b}$ & $13.5^{b}$ & $10.700^{b}$ & $0.68^{b}$ & $0.3000^{\mathrm{b}}$ & $0.5000^{b}$ \\
\hline Control & $0.070^{\mathrm{a}}$ & $16.5^{\mathrm{a}}$ & $13.6 \mathrm{a}$ & $0.81^{\mathrm{a}}$ & $0.40667^{\mathrm{a}}$ & $0.631^{\mathrm{a}}$ \\
\hline$\%$ Reduction & 24.28 & 18.2 & 21.32 & 16 & 26.22 & 20.7 \\
\hline
\end{tabular}

Means follow by the same letters are statistically insignificant.

\section{Antifungal activity of ethyl acetate crude extract}

The crude antibiotics of $P$. fluorescens were tested for their antifungal activities against the phytopathogenic fungi at the concentrations $25,50,75$ and $100 \mathrm{mg} \mathrm{ml}^{-1}$ in (Table 3 and Fig. 1). The crude antibiotics were found to record maximum $(100 \%)$ reduction of mycelial growth against $F$. oxysporium and $S$. rolfsii at the highest concentration. All tested concentrations reduced the mycelia growth of tested fungi. At the concentrations less than $25 \mathrm{mg} \mathrm{ml}^{-1}$, no inhibitory influence was observed against all tested fungi except $S$. rolfsii being very sensitive to all concentrations. Also, $S$. rolfsii recorded the lowest $\mathrm{EC}_{50}(21.54)$. Kavitha (2004) reported that crude antibiotics of $B$. subtilis and $P$. fluorescens inhibited the growth of $P$. aphanidermatum in turmeric. The crude antibiotics produced by P. fluorescens (CHA0) suppressed damping off disease in cucumber (Maurhofer et al., 1992). Indumathi (2012) also reported that crude antibiotic from $P$. aeruginosa (P1) showed maximum inhibition of mycelial growth of $F$. oxysporum $\mathrm{f}$. sp. dianthi. In addition, $B$. amyloliquefaciens and $P$. fluorescens were regarded as non-pathogenic bacterial species. Thus, the use of Pseudomonas as a biocontrol agent may be an environmentally safe way to suppress this plant disease.

Table 3: Efficacy of crude antibiotics produced by $P$. fluorescens against phytopathogenic fungi

\begin{tabular}{ccccccc}
\hline $\begin{array}{c}\text { Concentration } \\
\text { mg ml-1 }\end{array}$ & \multicolumn{7}{c}{ Reduction percentage of mycelia growth } \\
\cline { 2 - 7 } & $\begin{array}{c}\boldsymbol{F} \text {. } \\
\text { solani }\end{array}$ & $\begin{array}{c}\boldsymbol{F} \text {. } \\
\text { oxysporium }\end{array}$ & $\begin{array}{c}\boldsymbol{F} \text {. } \\
\text { Semitectium }\end{array}$ & $\begin{array}{c}\boldsymbol{R} \text {. } \\
\text { solani }\end{array}$ & $\begin{array}{c}\boldsymbol{S} \text {. } \\
\text { rolfisii }\end{array}$ & $\begin{array}{c}\boldsymbol{B} \text {. } \\
\text { cinerea }\end{array}$ \\
\hline $\mathbf{1 0 0}$ & $87^{\mathrm{b}}$ & $100.0^{\mathrm{a}}$ & $77.7^{\mathrm{d}}$ & $92.6^{\mathrm{c}}$ & $100.0^{\mathrm{a}}$ & $87.4^{\mathrm{b}}$ \\
$\mathbf{7 5}$ & $57.4^{\mathrm{d}}$ & $81.48^{\mathrm{b}}$ & $72.9^{\mathrm{c}}$ & $76.0^{\mathrm{c}}$ & $100.0^{\mathrm{a}}$ & $75.9^{\mathrm{c}}$ \\
$\mathbf{5 0}$ & $43.5^{\mathrm{c}}$ & $64.82^{\mathrm{b}}$ & $59.2^{\mathrm{b}}$ & $49.0^{\mathrm{c}}$ & $100.0^{\mathrm{a}}$ & $62.9^{\mathrm{b}}$ \\
$\mathbf{2 5}$ & $14.8^{\mathrm{d}}$ & $36.11^{\mathrm{c}}$ & $35.37^{\mathrm{c}}$ & $16.0^{\mathrm{d}}$ & $71.5^{\mathrm{a}}$ & $42.6^{\mathrm{b}}$ \\
$\mathbf{2 0}$ & - & - & - & - & $49.0^{\mathrm{b}}$ & - \\
$\mathbf{1 5}$ & - & - & - & - & $33.33^{\mathrm{c}}$ & - \\
$\mathbf{1 0}$ & - & - & - & - & $25.9^{\mathrm{d}}$ & - \\
$\mathbf{E C}_{\mathbf{5 0}}$ & 55.44 & 34.68 & 38.35 & 47.61 & 21.54 & 32.3 \\
\hline
\end{tabular}

Means follow by the same letters are statistically insignificant

\section{Scanning electron microscope}

Microscopic examination (SEM) of the control (untreated) showed that hyphae, were present in their normal condition. However, morphological abnormalities such as rupturing of hyphae and shrinkage, twisting, hydrolysis were observed on hyphae treated with crude antibiotics of $P$. fluorescens (Fig.2.). 

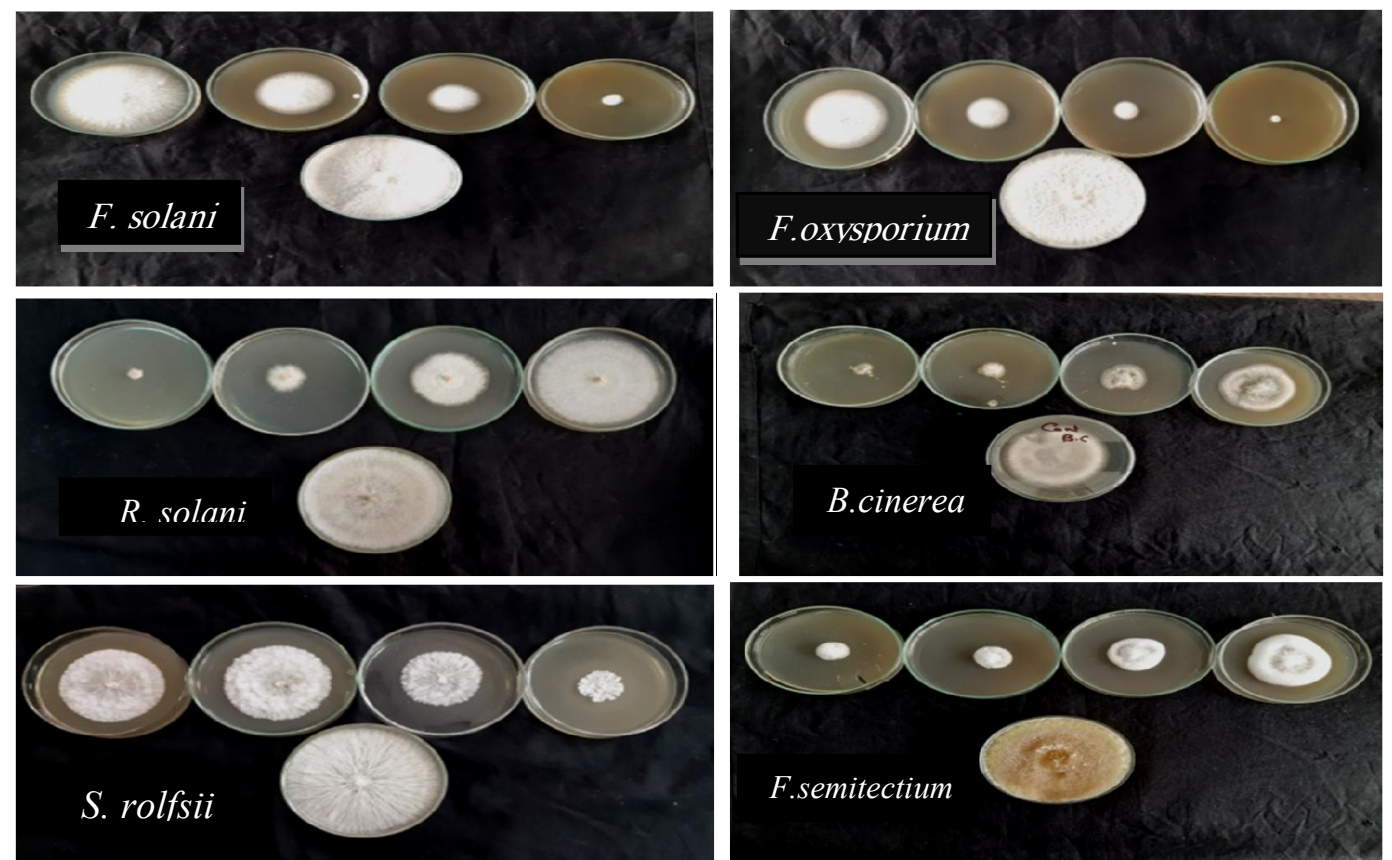

Fig. 1: Effects of crude antibiotics of $P$. fluorescens against phytopathogenic fungi.
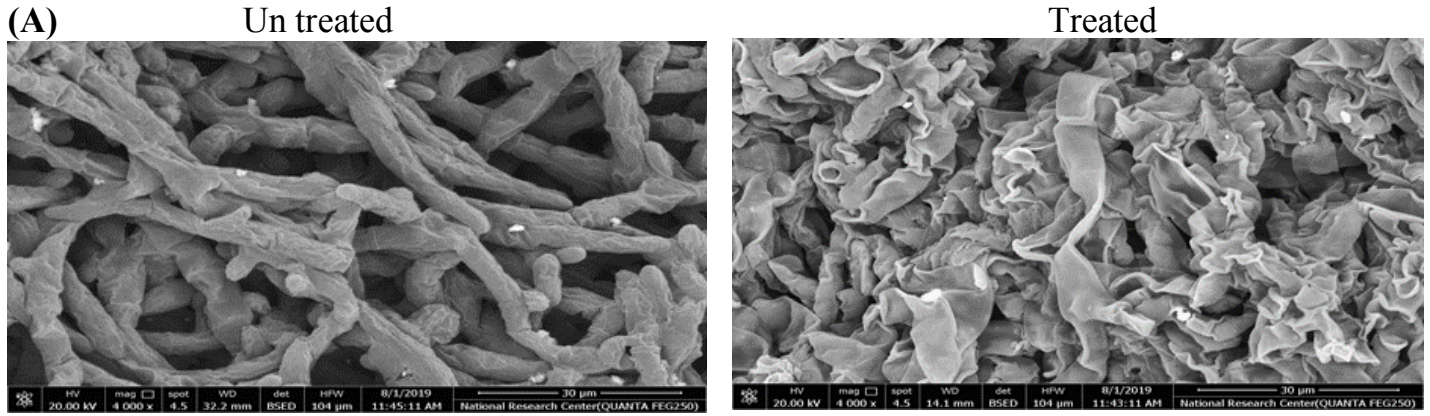

(B)
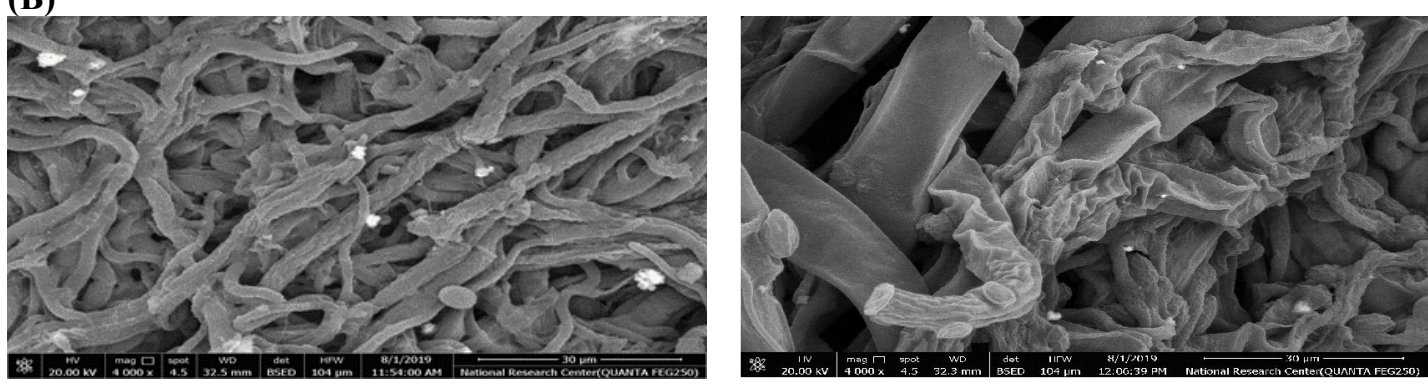

Fig. 2: Scanning electron micrographs of (A) R. solani and (B) B. cinerea treated with crude antibiotics of $P$. fluorescens.

\section{Identification and purification of antifungal compounds}

TLC of the metabolites produced by $P$. fluorescens showed five compounds. These compounds were purified and tested for antifungal activity by agar disk diffusion method (Mounyr et al., 2016). The five fractions were obtained from the column puriflash, Fraction no 1 showed in Fig. (3) has potential antifungal activity against phytopathogenic fungi. 


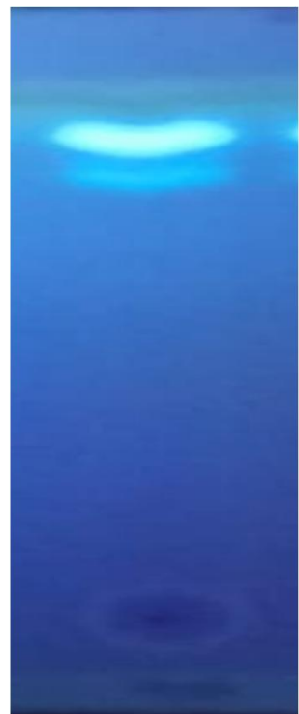

Fig. 3: TLC of the major fraction that has antifungal effect.

\section{Characterization and identification of antifungal compound}

\section{Mass spectroscopy}

Results revealed that the molecular weight of the antifungal compound was $255.4 \mathrm{~m} / \mathrm{z}$ (Fig. 4). This confirms that the antifungal compound extracted from $P$. fluorescens is pyrrolnitrin with the formula $\mathrm{C}_{10} \mathrm{H}_{6} \mathrm{Cl}_{2} \mathrm{~N}_{2} \mathrm{O}_{2}$. These results are in accordance with El-Banna and Winkelmann (1998) mass spectroscopy (negative ion spectrum) of PRN further confirmed (mass-to-charge ratio; m/z) at 256. High-resolution mass spectrometry of the two molecular ions gave $\mathrm{m} / \mathrm{z} 255.9826$ and 257.9777, respectively, indicating the molecular formula of $\mathrm{C}_{10} \mathrm{H}_{6} \mathrm{~N}_{2} \mathrm{O}_{2}{ }^{35} \mathrm{C}_{12}$ and $\mathrm{C}_{10} \mathrm{H}_{6} \mathrm{~N}_{2} \mathrm{O}_{2}{ }^{35} \mathrm{Cl}^{37} \mathrm{Cl}$ (Cartwright et al., 1995).

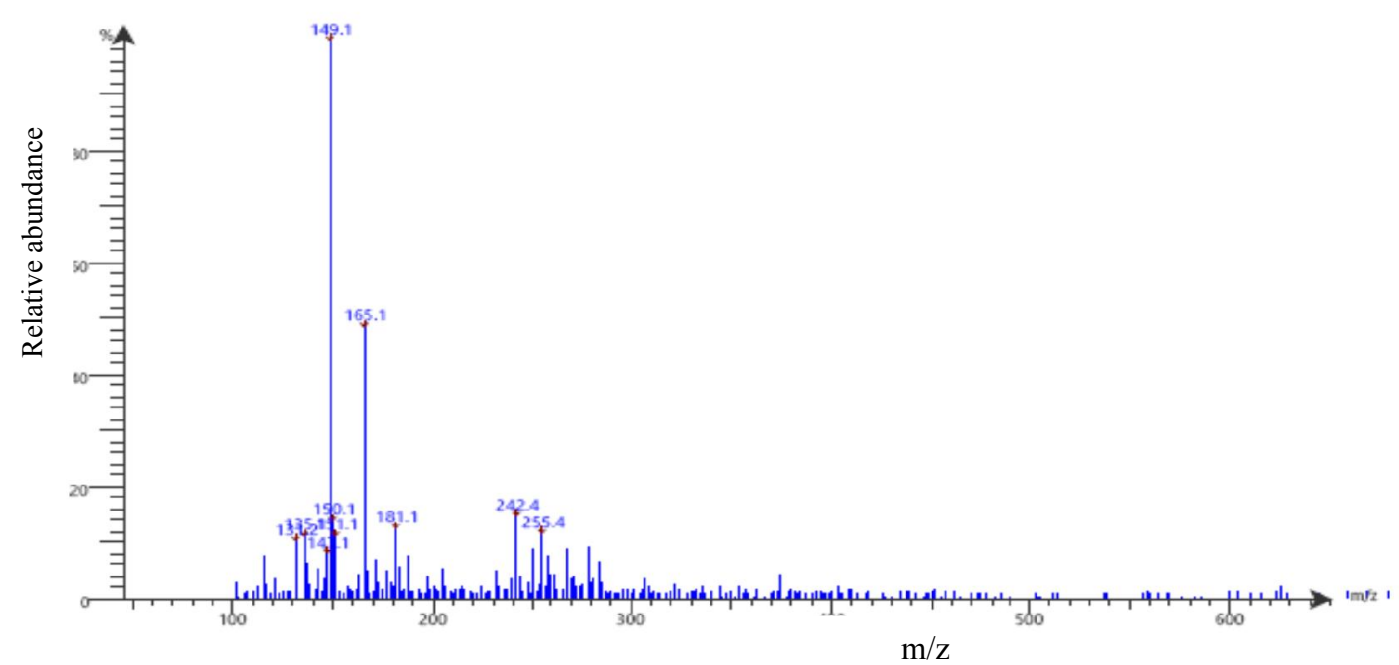

Fig. 4: TLC mass spectroscopy of pyrrolnitrin produced by $P$. fluorescens.

\section{Fourier Transform Infrared (FTIR) spectrum of antifungal compound}

In FTIR analysis, antifungal compound extracted from $P$. fluorescens revealed absorption at 3318.13 per $\mathrm{cm}$ pyrrole ring and $\mathrm{CH} 3$ (stretch) (1450.2) and $\mathrm{C}=\mathrm{C}$ aromatic weak intensity (1662.44), $\mathrm{C}^{-\mathrm{Cl}_{2}}$ (624.81). These results confirms that the antifungal compound is pyrrolinitrin (Fig. 5). These results are in the same trend of Shraddha et al. (2019). 


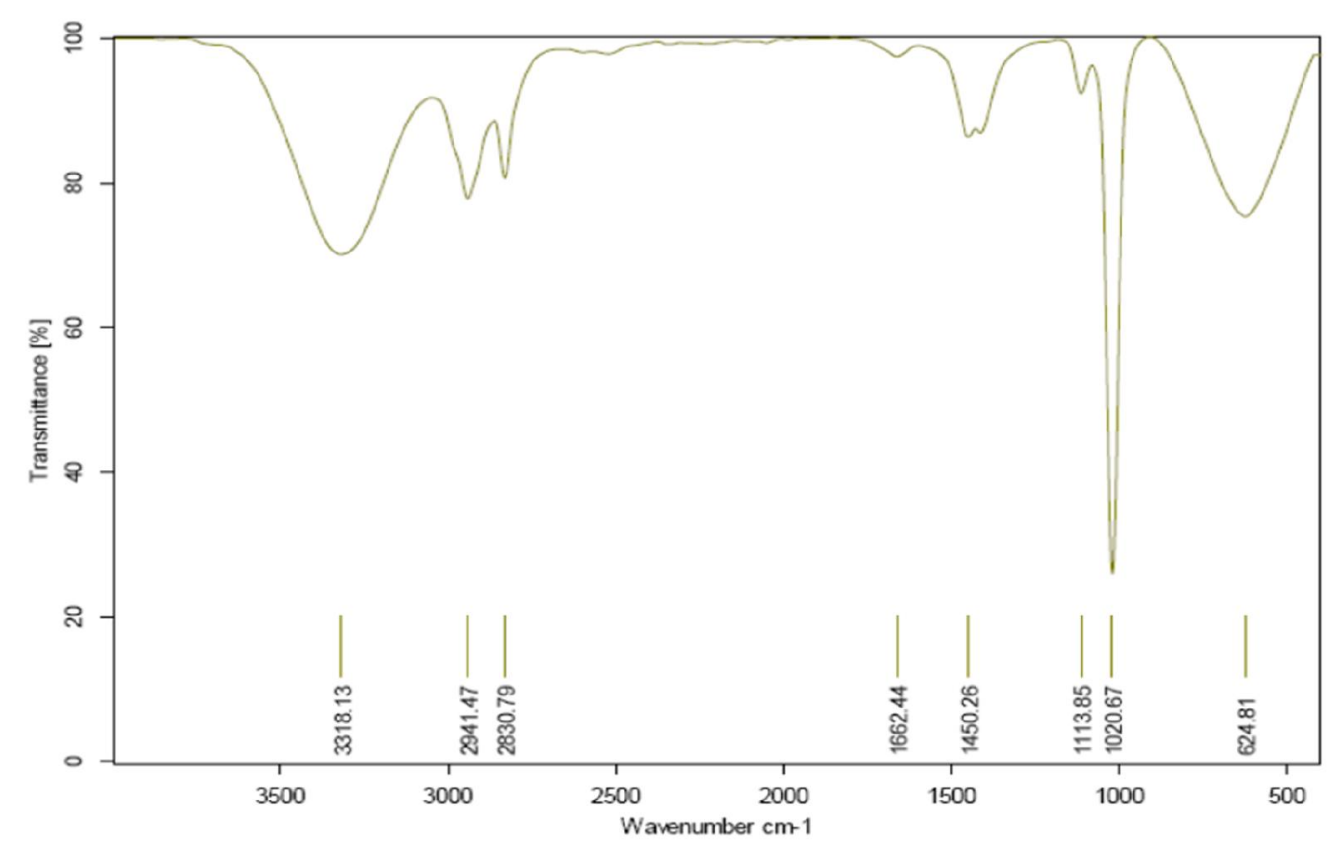

Fig. 5: FTIR for pyrrolnitrin produced by $P$. fluorescens.

From the previous results, the major compound in the antibiotic crude extract is pyrrolnitrin and this antibiotic affects the fungal cell through several mechanisms, the primary target of PRN lies in the cell membrane to impede protein, RNA, DNA synthesis and uncouple the normal electron flow in the respiratory electron transport chain (Warden and Edwards (1976). The metabolite has demonstrated biological activity at low concentration and act as an uncoupler of oxidative phosphorylation in Neurospora crassa. High concentration of PRN causes impairment of electron transport in flavin region and cytochrome c oxidase; accumulation of glycerol; synthesis of triacyl glycerol leading to leakage of cell membrane and inhibition of cell growth; in vitro activity against bacteria and fungi in the range of 1-100 $\mu \mathrm{g} \mathrm{mL}^{-1}$ (Di Santo et al., 1998). PRN also functions as a signal molecule, beyond its role as a bioactive molecule to suppress fungal and affected cell motility (Liu et al., 2018).

\section{References}

A.O.A.C., 1995. Official Methods of Analysis of the Association of Official Analytical Chemists. $15^{\text {th }}$ ED. Published by association of official analytical chemists. INC. suite 400.200 Wilson Baulevard-Arligton Virgina 22201 USA., pp. 69-90.

Abd El-Ghany, K.M., 2001. Studies on root rot of mango seedlings. M.Sc. Thesis, Fac. Agric., Cairo univ., $131 \mathrm{P}$.

Alimi, M., M. Javad soleimani and M.T. Darzi, 2012. Characterization and application of microbial antagonists for control of Fusarium head blight of wheat caused by Fusarium graminearum using single and mixture strain of antagonistic bacteria on resistance and susceptible cultivars. Afr. J. Microbiol. Res., 6: 326-334.

Barrett, H.L. and B.B. Hunter, 1987. Illustrated genera of imperfect fungi. Mac Millan Publishing Company. New York and Mac Millan Publishers, London, 220 P.

Burr, T.J., J.E. Hunter, J.M. Ogawa, and G.S. Abawi, 1978. A root of apple caused by Rhizoctonia solani in New york nurseries. Plant Dis. Reptr., 62(6):476-476.

Cartwright, D.K., W.S. Chilton, and D.M. Benson, 1995. Pyrrolnitrin and phenazine production by Pseudomonas cepacia, strain $5.5 \mathrm{~B}$, a biocontrol agent of Rhizoctonia solani. Appl. Microbiol. Biotechnol., 43: 211-216.

De Vrieze, M., P. Pandey, T. D. Bucheli, A.R. Varadarajan, C.H. Ahrens, and L. Weisskopf, 2015. Volatile organic compounds from native potato associated Pseudomonas as potential antioomycete agents. Front. Microbiol., 6:1295. 
Dewez, D., L. Geoffrory, G. Vernet and R. Popovic, 2005. Determination of photosynthetic and enzymatic biomarkers sensitivity used to evaluate toxic effects of copper and fludioxonil in alga Scenedesmus obliquus. Aquatic Toxicol., 74:150-159.

Dhingra, O.D. and J.B. Sinclair, 1984. Basic Plant Pathology Method. CRC, Boca, Raton Florida, USA.

Di Santo, R., R. Costi, M. Artico, S. Massa, G. Lampis, D. Deidda, and R. Pompei, 1998. Pyrrolnitrin and related pyrroles endowed with antibacterial activities against Mycobacterium tuberculosis. Bioorg. Med. Chem. Lett., 8: 2931-2936.

Dixon, R.A., 2001. Natural products and plant disease resistance. Nat., 411: 843-847.

Duncan, D.B., 1955. Multiple Range and Multiple, F-test Biometrics, 11(1):1- 42.

El-Banna, N. and G. Winkelmann, 1998. Pyrrolnitrin from Burkholderia cepacia: Antibiotic activity against fungi and novel activities against streptomycetes. J. Appl. Microbiol., 85(1): 69-78.

Gomez K.A. and A.A. Gomez, 1984. Statistical Procedures for Agriculture Research. $2^{\text {nd }}$ Ed., June Wiley \& Sons. Inc. New York.

Indumathi, T., 2012. Biological and chemical control of carnation wilt incited by Fusarium oxysporum Schlechtend: F. o. f. sp. dianthi (Prill \& Delacr.) W.C. Snyd. \& H.N.Hans, under protected cultivation. M.SC. Thesis. TNAU.

Jayaraman, J., 1985. Laboratory Manual in Biochemistry. pp.132-135. Wiley Eastern Limited. New Delhi, N.Y.

Karima, H.E. Haggag and Nadia, G. El-Gamal, 2012. In vitro study on Fusarium solani and Rhizoctonia solani isolates causing the damping off and root rot diseases in tomato. Nature and Science, 10:(11).

Kavitha, K., 2004. Molecular and biochemical approaches for the selection of biocontrol agents for the management of turmeric rhizome rot. Ph.D., (Ag.) Thesis, Department of Plant Pathology, Tamil Nadu Agricultural University, Coimbatore-3. India, pp. 65-67.

Kliebenstein, D.J., 2004. Secondary metabolites and plant/environment interactions: A view through Arabidopsis thaliana tinged glasses. Plant Cell Environ., 27: 675-684.

LiHua, C.Y., Z. Zhang, B. Li, G. Qin, and S. Tian, 2018. Pathogenic mechanisms and control strategies of Botrytis cinerea causing post harvest decay in fruits and vegetables. Food Quality and Safety, $2(3): 111-119$.

Liu, X., X. Yu, Y. Yang, S. Heeb, S. Gao, K.G. Chan, M. Camara, and K. Gao, 2018. Functional identification of the prnABCD operon and its regulation in Serratia plymuthica. Appl. Microbiol. Biotechnol., 102: 3711-3721.

Loper, J. E., K.A. Hassan, D.V. Mavrodi, E.W. I. I. Davis, C.K. Lim and B.T. Shaffer, et al., 2012. Comparative genomics of plant-associated Pseudomonas spp.: insights into diversity and inheritance of traits involved in multitrophic interactions. PLOS Genet., 8:e1002784.

Lowery, O.H., N.J. Rosebrough, A.L. Farr, and R.J. Randall, 1951. Protein measurement with the folin phenol reagent. J. Biol. Chem., 193:265-275.

Mallaiah, B., E. Rahinikanth, G. Manjulatha and M. Muthamilan, 2017. Isolation and identification of antifungal compounds from Pseudomonas fluorescens inhibiting the growth of Fusarium incarnatun (DESM.) SACC. incitant of crossandra wilt. Nat. Environ. Ass., 12(1):199-203.

Maurhofer, M., C. Keel, U. Schneider, C. Voisard, D. Haas, and G. Defago, 1992. Influence of enhanced antibiotic production in Pseudomonas fluorescens strain CHA0 on its disease suppressive capacity. Phytopathol., 82:90-195.

Mounyr, B., S. Moulay, and K. I. Saad, 2016. Methods for in vitro evaluating antimicrobial activity: A review. J. Pharma. Anal., 6:71-79.

Nelson, P.E., T.A. Toussoun, and W.F.O. Marasas, 1983. Fusarium species on illustrated manual for identification. Pennsylvania Stat University Press, University Park, 193P.

Prabhukarthikeyan, S.R. and T. Raguchander, 2016. Antifungal metabolites of Pseudomonas fluorescens against Pythium aphanidermatum. J. Pure Appl. Microbiol., 10(1):579-584.

Rohit, K. M., P. Om, K.T. Amit, P. Anand, A. Mansoor, and D. Anupam, 2011. Culture filtrate antibiosis plant growth promoting rhizobacteria PGPRs against phytopathogens infecting medicinal and aromatic plants. Int. J. Res. Biol. Sci., 1(4):45-5.

Rosales, A.M., L. Thomashow, R.J. Cook, and T.W. Mew, 1995. Isolation and identification of antifungal metabolites produced by rice associated antagonistic Pseudomonas spp. Phytopathol., 85(9):1029-1032. 
Shraddha, P., C. Ambalal, P. Ratna, S. Renu, and P. S. Dhananjaya, 2019. Microbial pyrrolnitrin: natural metabolite with immense practical utility. Biomol., 9(9): 443.

Siddiqui, I.A., S. Ehteshamul-Haque, and S.S. Shaukat, 2001. Use of rhizobacteria in the control of root-rot knot disease complex of mungbean. J. Phytopathol., 149(6):337-346.

Sreenivasulu, N., S. Ramanjulu, K. Ramachandra-kini, H.S. Prakash, and C. Sudhakar, 1999. Total peroxidase activity and peroxidase isoforms as modified by salt stress in two cultivars of fox-tail millent differential salt tolerance. Plant Sci., 141:1-9.

Trolezi, R., J.M. Azanha, N.R. Paschoal, J.L. Chechi, M.J. Dias Silva, V.E. Fabris, W. Vilegas, R. Kaneno, A. Fernandes Junior, and S.M. Bosco, 2017. Stryphnodendron adstringens and purifed tannin on Pythium insidiosum: in vitro and in vivo studies. Ann. Clin. Microbiol. Antimicrob., 23, $16(1): 7$.

Van der Does, H.C., M.E. Constantin, P.M. Houtermar, and L.W. Taken, 2019. Fusarium oxysporium colonizes the stem of resistant tomato plants, the extent varying with the R-gene present. Eur. J. Plant Pathol., 154:55-65.

Wagner, A., S. Norris, P. Chatterjee, P. F. Morris and H. Wildschutte, 2018. Aquatic pseudomonads inhibit oomycete plant pathogens of glycine max. Front. Microbiol., 9:1007.

Warden, J.T. and D.L. Edwards, 1976. Electron spin resonance investigations of mitochondrial electron transport in Neurospora crassa: Characterization of paramagnetic intermediates in a standard strain. Eur. J. Biochem., 71:411-418.

Yasmin, S., A. Zaka, A. Imran, M. A. Zahid, S. Yousaf and G. Rasul, 2016. Plant growth promotion and suppression of bacterial leaf blight in rice by inoculated bacteria. PLOS One, 11:e0160688.

Zhang, L., S. E. Khabbaz, A. Wang, H. Li and P.A. Abbasi, 2014. Detection and characterization of broad-spectrum antipathogen activity of novel rhizobacterial isolates and suppression of Fusarium crown and root rot disease of tomato. J. Appl. Microbiol., 118:685-703. 